\title{
カラマツ材の.防カ ビ
}

\section{1.はしがき}

石油パニック前の昭和47年にお㹁る科学技術庁 の資源白書において、すでに10年以内に資源不足 が心配されるものとして、水、石油、林産物があ げられている。とくに、同じ生物資源である農産 物に比較し木材資源で問題なのは、資源の再生産 サイクルであり、これからくる将来の資源不足と 小径級化など品位の低下である。これら原材料の 質の低下に対処すると共に貴重な国内木材資源の 有効利用を図るためには、保存処理技術の開発が 極めて必要なことである。カラマッの防カビ処理 技術の開発も、この材の有効利用のら光から不可 避であり、また急務である。

一方、防カビ処理に用いられてきた木材防菌㧩 のららには量産化時代に即応し效用面だけが要求 されたため、カビに対し強い殺菌力をもつ反面、 残留毒性や皮虞粘膜に対する直接の刺戟が強く作 業者の安全上問題のあるるのも使用されてきた。 このことは、防カビ処理等の作業に従事する人に 対する等衝安全衛生上の問題ばかりでなく、更に 二次加工作業者あるいは最終需要者までも被害が 発展する可能性をもっている。

農薬の安全性、環境污染が問題化し低瑇性薬郕 の開発が進みつつある今日を契機に、従来の薬用
布 村 昭 夫*

に代替できる安全性の高い低毒性薬珮を選択する ことは極めて重要なことと思われる。折角の機会 でもあり、カラマッ材の防カビと題してこれらの 現状などについて若干触れてみることにする。

\section{2. カラマツ資源と利用の現況}

\section{1. カラマツ資源}

全国のカラマツ資源は概小面積にして 100 万ha であり、蓄積は 4, 660万 $\mathrm{m}^{3}$ に達している。これら の府県別数量は第1表に揭げるとおりであり、こ の中で最も生産量の多い北海道は面積、蓄積とも に略々その半数を占めている。長野、岩手、山梨 がこれに続いており、これらの総数は全国の90\% を超元に至っている。これらは何れも、戦後に 造林された20年生末満の若齢林が大半を占めてい るため育林、保育を必要としており、従ってこれ からの間伐材の利用、需要の開発が今日の課題と なっている。また、全国の素材生産量は第 2 表に 示すと㧍り略々430〜450万 $\mathrm{m}^{3} に$ 達しているが、こ の.うち約 $90 \%$ 北海道に揖いて生産されている。 一方外材輸入量は建築構造材の需要増によって一 時大幅な不足を生じた昭和48年を契機に增加し始 め、今日ではカラマッ製材の $5 \%$ を外材製品によ っている。

第1表 全国カラマッ餈源の現況（カラマッ生産主要県の計）・概数 単位：千ha 千 $\mathrm{m}^{3}(\%)$

\begin{tabular}{|c|c|c|c|c|c|c|c|c|c|c|c|c|c|}
\hline 区 分 & 総 & 数 & 海道 & 青 森 & 大田 & 山形 & 岩手 & 宮城 & 福 島 & 杤 木 & 長野 & 山梨 & 群䭴 \\
\hline 面 積 & .0 & 00 & 51 & - & $(1.6)$ & (1.3) & $(10.2)$ & (1.1) & $(2.9)$ & $(1.0)$ & $(24.5)$ & (4.1) & $(1.8$ \\
\hline 蓄 積 & 46,588 & $00.0)$ & $(48.1)$ & - & $(0.8)$ & (1.1) & $(12.9)$ & $(0.8)$ & (2.3) & $(0.8)$ & $(27.7)$ & $(2.8)$ & $(2.7)$ \\
\hline
\end{tabular}

（注）48 50年度カラマツ生産関係道県連絡協議会資料より算出。

$*$ 北海道立林産試験場 林産化学部長 


\begin{tabular}{c|c|c|c|c|c|c|c|c|c|c|c|c|c|c}
\hline 区 分 & 生 産 量（素材). & 北海道 & 青森 & 岩手 & 宮城 & 秋田 & 山形 & 福島 & 栃木 & 群馬 & 世梨 & 長野 & 只の他 \\
\hline 46 & 452 & $(100)$ & $(88.6)$ & $(0.2)$ & $(1.5)$ & $(0.1)$ & $(0.2)$ & $(0.1)$ & $(0.6)$ & $(0.3)$ & $(1.5)$ & $(0.8)$ & $(5.5)$ & $(0.6)$ \\
\hline 47 & 454 & $(100)$ & $(89.7)$ & $(0.4)$ & $(1.3)$ & $(0.1)$ & $(0.3)$ & $(0.1)$ & $(0.5)$ & $(0.2)$ & $(1.3)$ & $(0.7)$ & $(4.8)$ & $(0.6)$ \\
\hline 48 & 432 & $(100)$ & $(88.3)$ & $(0.4)$ & $(1.6)$ & $(0.2)$ & $(0.2)$ & $(0.1)$ & $(0.6)$ & $(0.2)$ & $(1.3)$ & $(0.7)$ & $(5.8)$ & $(0.6)$ \\
\hline
\end{tabular}

（注）力ラマツ生産関係道県連絡協議会資料

第 3 表 カラマッ製材の用途別出荷実繢

単位：千 $\mathrm{m}^{3}(\%)$

\begin{tabular}{|c|c|c|c|c|c|c|c|c|c|c|c|c|c|}
\hline \multirow{2}{*}{ 区 } & \multirow{2}{*}{$i$} & \multirow{2}{*}{ 忩 数 } & \multicolumn{2}{|c|}{ 建 築 用 } & \multicolumn{2}{|c|}{ 土木 用 } & \multirow{2}{*}{ 梱包材 } & \multirow{2}{*}{\begin{tabular}{|l} 
製崡材 \\
仕組板
\end{tabular}} & \multirow{2}{*}{$\begin{array}{l}\text { ダンネ } \\
\text { ージ }\end{array}$} & \multirow{2}{*}{$\begin{array}{l}\text { ドラム } \\
\text { 材 }\end{array}$} & \multirow{2}{*}{$\begin{array}{l}\text { パレッ } \\
\text { ト材 }\end{array}$} & \multirow{2}{*}{ 足場板 } & \multirow{2}{*}{ その他 } \\
\hline & & & 㮖造材 & 仮設材 & 樓造材 & 仮設材 & & & & & & & \\
\hline \multirow{3}{*}{48} & 量 & $\begin{array}{l}135,3 \\
(100)^{3}\end{array}$ & $\begin{array}{c}32,1 \\
(23.7)\end{array}$ & $\begin{array}{l}8.6 \\
(6.4)\end{array}$ & $\begin{array}{l}2.2 \\
(1.6)\end{array}$ & $\begin{array}{c}17.4 \\
(12.9)\end{array}$ & $(28.8)$ & $\begin{array}{l}5.6 \\
(4.2)\end{array}$ & $\begin{array}{l}11,8 \\
(8.7)\end{array}$ & & $\begin{array}{r}8.8 \\
(6.5\end{array}$ & $=$ & $\begin{array}{l}5 \\
(4\end{array}$ \\
\hline & 内 & 57 & 2 & 5,1 & 1,4 & 0.1 & 2,8 & 4,2 & , & 0,4 & 5 , & - & \\
\hline & 道外 & 17. & . & 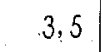 & 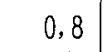 & 10.5 & 36,2 & 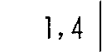 & 10,0 & & 3.7 & - & $\because$ \\
\hline \multirow{3}{*}{49} & 量 & $\begin{array}{l}102,7 \\
(100)\end{array}$ & $\begin{array}{c}22,8 \\
(22.2) \\
\end{array}$ & $\begin{array}{r}6.1 \\
(5.9) \\
\end{array}$ & $(1,1)$ & $\begin{array}{l}10.2 \\
(9.9)\end{array}$ & $\begin{array}{c}25,1 \\
(24.4)\end{array}$ & $\begin{array}{c}5,7 \\
(5.6) \\
\end{array}$ & $\begin{array}{l}16,4 \\
(16.0)\end{array}$ & $(1,6)$ & $\begin{array}{c}11,1 \\
(10.8)\end{array}$ & -1 & (2) \\
\hline & 道内 & 42,3 & 17,7 & 3 & 0,5 & 5 & 2,1 & 3,3 & 1,7 & 0,1 & 5,7 & - & 2.0 \\
\hline & 道外 & 60,4 & 5,1 & 2,2 & 0,6 & 5,1 & 23,0 . & 2,4 & 14,5 & 1,5 & 5,4 & - & 0 , \\
\hline
\end{tabular}

（注）道林務部調（カラマッ製材流通調查）

\section{2. カラマッ利用の現況}

昭和48、49年度におけるカラマッ製材の用途別 出荷量は第3表のとおりであり、年間総計 10〜14 万 $\mathrm{m}^{3}$ に達している。この中の $80 \%$ は建築用材、相 包材、ダンネージ材、パレット材等であり、その 60\%は北海道より京浜を中心にした道外へ移出さ れている。これら製材用カラマツ原木の径級割合 では14〜18cmのbのが鼠も多くついで8〜13cm と なって扣り、これらの径級の小さいものが総原木 消費量の80\%近くを占めている。従ってこれから 得られる製材品は、直接力ビや变色菌による被害 の刘象となる辺材の混入率が極めて高く、これら の菌害を生じないための防カビ処理の必要度が高 い製品が、大部分を占めているのが現状である。

\section{3. 木材のカビとカラマッ材のカビ}

\section{1. 木材のカビ}

一般に木材は適当な温度 $\left(20 \sim 30^{\circ} \mathrm{C}\right)$ と水分 (含 水率 30～60\%、哭係湿度 80～100\%）柿ると大 いに菌害を受けやすく、とくに高温、多湿の5〜
6月になると一ミセルロース、楉類などに富む 辺材にはこれらを栄養源として变色を伴らカビ (mold) が発生しやすい。この時期には比較的 湿度の低い北海道に求いて子製材直後のマッ材 や、天乾中の製材、スライス直後のつき板や単板 等とくに含水率の高い生材状態のま通風、換気 の悪い會㡺や室内に保管された際には、材料の表 面でのカビの発生は顕著である。この他特殊な例 として、近年室内環境（密閉度）が向上したた め、台所、浴室、脱衣場等での湿度が高まりやす く、このためこれらの周围に使用されている新建 材などでの基材と表面材料（塗料など）との中間 での力ビ発生が目立ってきている。また、この 5 〜6月には、カビの胞子の生育条件が良く活澄な 発育をするため、一旦、材に飛散した胞子は充分 な水分があると10時間前後で発芽し、数日間のう らにつぎつぎと菌系が生長をとげると云われてい る。これらのカビにより青変のほか黒変、オレン ジスティンなどを生ずる。これら変色、污染の原 因となるカビの種類は多く、青变をおこすものと 
しては Penicillium, Aspergillus, Trichoderma などがあり、黒変を抏こするのとしては、Alter naria, Pullularia, Chaetophoma, Cladosporium などが知られている。またFusariumはオレンジ スティンの原因となるカビである。これらは、い ずれも木材表面上に発生するものであり、その污 染は菌系独自の色扣よび菌系の分泌する色素によ る表面污染であるため、表面の鉋削により一応污 染は除けらるが、防カビ処理を施さない限り、使用 環境により再び発生をみる可能性が残る。一方菌 系が材組織に深く侵入し、材中のへミセルロース や糖類を栄養源として生育して材を变色 (Stain) させる菌類を、木材変色菌と呼んでいる。このう ち青変菌による青変は最も普通にマッ類などの辺 材に見られる変色 (Blue stain 又は Sap stain) であり、とくにエゾマッの辺材にはクワイカビ科 Ophiostomataceae に属するエゾマックワイカビ が良く発生する。これら青変菌は約30種類知られ ており、トドマツ、モミ、ブナ、ミズナラのほか カラマツ辺材にも発生する。梅雨時に青変菌の被 害が多発するのは、カビ同様、高温、多湿が生育 に適するためであり、針葉樹の場合、その辺材内 部の仮導管中に菌系が生育伸長し、有縁膜孔を貫 通して隣りの仮導管に侵入する。更に放射組織に 沿って半径方向に辺材深く侵入するため、カビの 場合と異なり表面の鉋削で污染を除去することは できない。変色菌の中には褐変菌も存在する。こ れら菌類による污染のほか水中眝木材などで材が 酸性下に扮かれた時、酸化酵素活性が増大し、こ のため木材中のフェノール物質等の酸化に基づく 着色が促進される所謂化学污染が、近年、人工乾 燥室内で起こる例（ストローブ松の污染防止には アルカリ処理が良いと検討されている）などがあ るが直接菌類によるものと区別される。

カビ、変色菌のいずれもこの段階ではセルロー ス、リグニン等の構成要素を殆んど侵さないので 外観上の欠点は大きいが、材の強度には著しい影 響を与えない。従って構造用材としては短期的に は支障を来さないと見る向きも多いが、青変した 材は次第に水を多く吸着することが知られてお り、木材の腐朽の可能性が増大するし、時には初 期腐朽が同時に存在する場合もあるため、早期に
防カビ処理を施す必要がある。

\section{2. カラマツ材のカビ}

写真 】は製材直後のカラマッ粗挽材辺材が生材 のまま結束され土場に置かれたとき、内層を中心 に発生したカビの発生状況を示すものである。写 真上部の全面を覆った黒い部分はPenicillium に よる青変部であり、中央部の斑点状の黒の部分は Mucorによる黒変部である。斑点の出方によって 外国では speck, spot, patchなどと呼称されてい るが、殆んど区別されにくい。これらの状況は発 生環境（水分、樹種、表面性状、感染機構）など によって時により様々な形を呈すると云われる。 写真 2 はカラマッ防カビテストに用いた鉋削仕上 げした無処理カラマツ辺心材の供試材を $20^{\circ} \mathrm{C} 、 85$ $\%$ R. H. の室内に約 3 週間放置後表面に発生した Aspergillus と Penicillium の青力ビの発生状況

\section{写真】カラマッ製材品に発生したカビ（辺材部）}

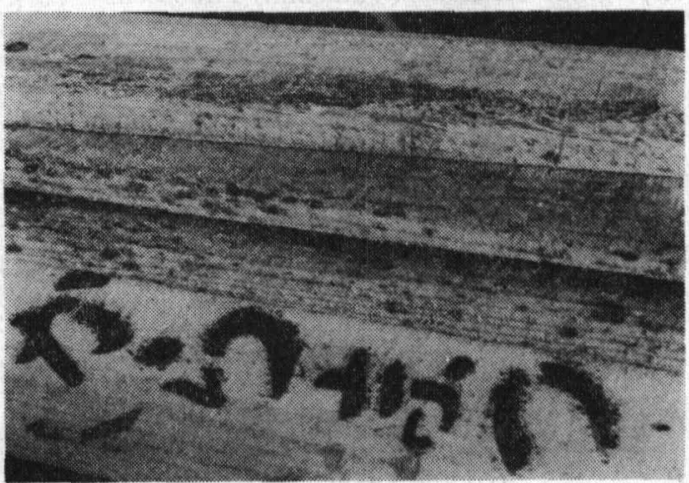

写真 2 カラマッ供試材に発生した青カビ

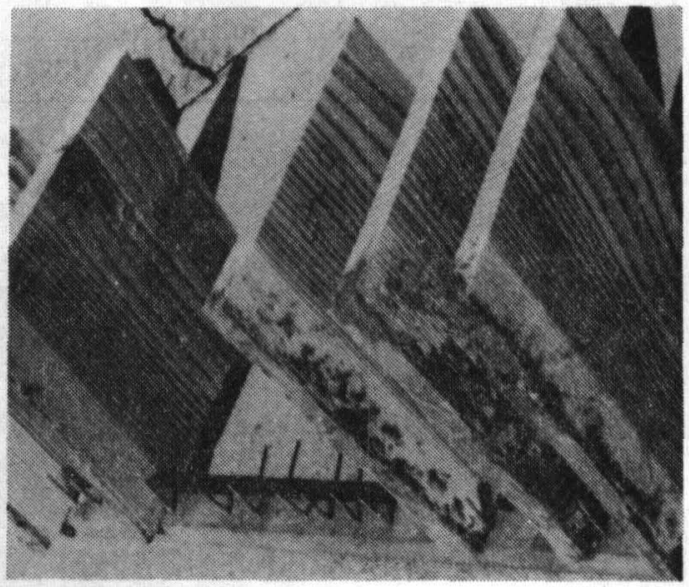


を示したものであり、葡萄糖馬鈴薯寒天を用いた 平板塗沫法によりこれらを分離同定した結果、写 真 3 の 2 種を始め、第 4 表に示す 2 属 10 種の青力 ビが確認されている。

\section{写真 3 シャーレ中の青カビの発生状況}

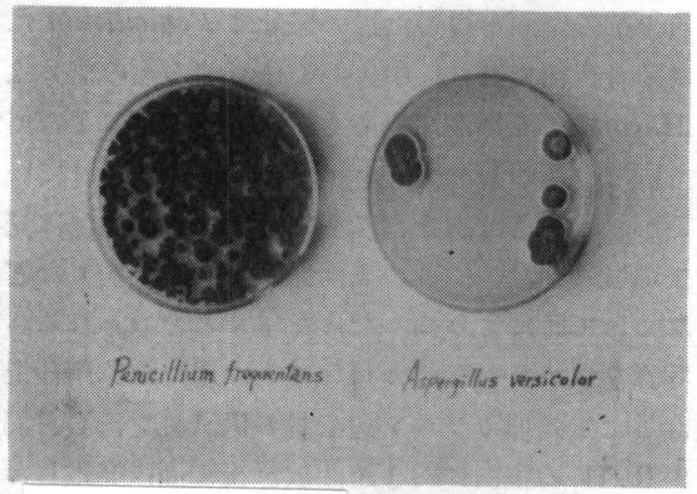

Penicillium frequentans

Aspergillus versicolor

第 4 表 各試料木片より得られたカビと株数

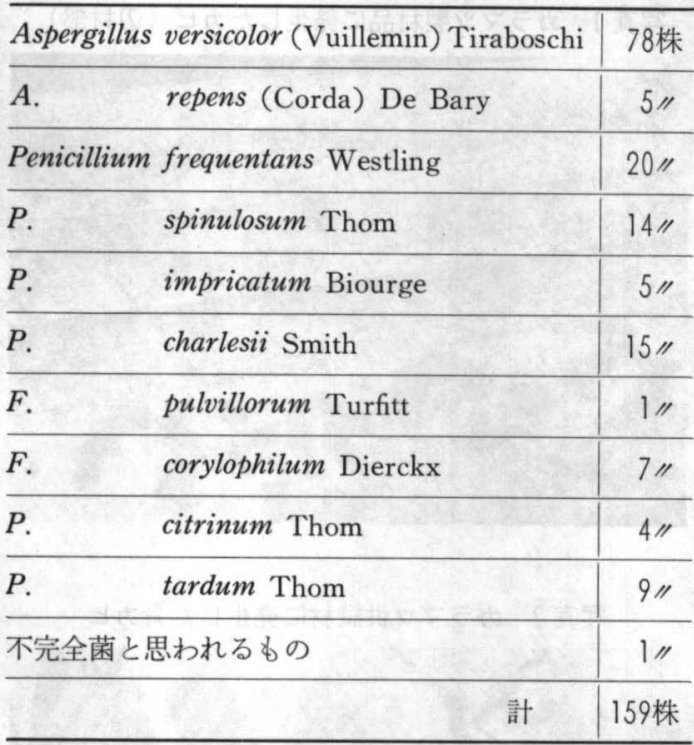

\section{4. 木材防菌剤とカラマッ材の防カビ試験}

\section{1. 木材防菌剤}

わが国で木材に発生するカビや变色菌を防止す る防菌剤としてこれまで使われてきた種類は多い が、これらのらちの代表的なものの一つにペンタ クロルフェノールをあげることができる。戦後イ ンチ材の輸出が旺んになった昭和30年頃から、こ のペンタクロルフェノールの油剤に浸漬または水 溶液（ナトリウム塩）の噴霧処理が行なわれ、輸
出ナラインチ材の防菌処理剤として大きな役割を 果してきた。一方、国内においてもコンテナ輸送 が増えるにつれ、夏期の高温期には、輸送中のカ ビ発生例が多く、これらの防止に使用されてき た。このペンタクロルフェノールは強い殺菌性を ๖つと同時に、植物に対する作用も強く、除草剤 としても多用されてきたが、人体に対する毒性が 高く、取扱上の不注意等により木材防力ビ、防虫 処理使用時に死亡事故をおこした例も二、三知ら れている。マウスに対する中央致死量 $\mathrm{LD}_{50}$ は78 $\mathrm{mg} / \mathrm{kg}$ （ナトリウム塩 $72 \mathrm{mg} / \mathrm{kg}$ ) であり、劇毒物区 分上は劇物に入る。この直接の毒性よりもむしろ 皮膚に接するときの刺激作用が強いため、直接の 粉体または蒸気の吸入による咽喉内部の粘膜の脬 腫、嘔吐、発熱を伴ら虚脱症状や、直接接触した 皮膚における発疹、膿腫の形成などをおこす例が 多い。このため、労働安全対策上、有害な特定化 学物質として使用事業所の届出、取扱上の注意、 作業員の健康状態の報告義務等の行政上の指導措 置が取られた。

一方、近年、昭和31年に発見された有機水銀に よる神経疾病が所謂水俣病として認定され、魚類 等での残留量や残留農薬の毒性問題が急激に表面 化した。更には、国際的水準において F A O の中 でのWHO農薬委員会を中心にする有機塩素、り ん系等農薬（とくに発癌性関連物質などの）の残 留規制強化の方向がアメリカにおいて活溌化し、 わが国での農薬に対する考方も次第に安全性を 重視する方向に移り、ドリン剂、D D T、B H C 等残留性有機塩素剤の使用禁止にまで発展した。

木材防虫剤の場合には、処理された材料に含ま れる薬剤と人体との接触、人体への流入の機会等 が比較的少なく、これそよる影響が農業製品など からより直接的でないことと、海外での使用規制 の状況も判然としたものを設けていないことなど から一時完全な禁止措置はとられなかったが、代 替薬剤の使用上の見通しも出て来たので、次第に 安全サイドをとって上記残留性有機塩素剤の使用 禁止がなされた。木材防菌剤の場合も、当然これ らと同じく安全性を保つ方向が望ましく、薬剤自 体の低毒化と取扱上の安全性の期待できる薬剤の 開発への方向に進みつつある。 
先に触れたペンタクロルフェノールの場合の低 毒化の手段としては、ロジンアミン塩（デとドロ アビェチルアミン塩)、ラウレート（ラウリル酸エ ステル）、第 4 級アンモニウム塩（セチルトリメチ ルアンモニウム塩）などの誘導体にすることによ り、分子量を大きくして蒸気圧を下げ蒸散を少く し耐候性をあげると共に、ペンタクロルフェノー 几単体の白色針状結晶化を防いで粉末の飛散吸入 を防止し、取报上の安全性を図ったペンタクロル フェノール誘導体が商品化され、市販品として子 出超ってきている。勿論、この際有効成分が減る ため效力も低下するが、毒性も低下し取报上普通 物となる。更にこの際、元来ペンタクロルフェノ ール工業製品中に含まれる毒性の高い不純物（四 塩化ベンゾダイオキシン) が精製除去されれば実 質的な低毒化はさらに進むことが期待できる。

\section{2. カラマッ材の防カビ試験}

近年、低毒性防菌㓮の開発が各国で進められ、 木材防菌㨈として子市服されてきているが、これ らの実用效力データが不足している。おが国で は、現在末だこれらの木材防菌凨や防虫肪に対す る効力を確かめる試験方法が確立していない。一 般にはJ I S Z 2911 工業製品なたは工笠材料の カビに対する抵抗性試験法が一部に用いられてい るが、とくに実用上は、従来用いられてきたペン タタロルフェノールなどに比べてどの程度の効力 を示寸かを知ることが重要である。

このため、カラマツ材の防カビ試験として、最 近の木材防菌剈のうちから経口毒性 $300 \mathrm{mg} / \mathrm{kg}$ 以下 の低毒性薬㓮10種を選び尒供試験を行いこの結 果から無処理と大美なかったもの5種を除いて効 力の高かった 5 種のハロゲン系薬剛（第 5 表）を 使用し、カラマツ辺心材に用いたときの効力をぺ ンタクロルフェノールおよび無処理材と比較し た。その結果は第6表のとおりである。供試した カラマッ辺心材は $0.8 \times 15 \times 15 \mathrm{~cm}$ (辺材幅 $4 \sim 7$ cm）の鉋仕上げした板材であり、これに各供試薬

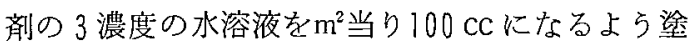
布したのち、20 C、85\% R.Hの恒温恒湿室に 4 ケ 月放置し、その間に括けるカビの発生状況を肉眼 観察して効力を検討した。表中の数字はカビの生 育程度の観察結果を示し、発生せず 0から、極め
第 5 表 供試防カビ薬郕の成分と毒性

\begin{tabular}{|c|c|c|c|}
\hline 薬 珮 & 成 分 (製 剂) & 毒 性 & $\begin{array}{l}\mathrm{L} \mathrm{D}_{50} \\
(\mathrm{mg} / \mathrm{kg})\end{array}$ \\
\hline A & $\mathrm{P} C \underset{\text { (乳 }}{\mathrm{P}}$ ラウ剂) & 普通物 & 750 \\
\hline B & 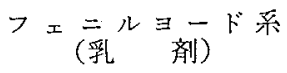 & $"$ & 1,250 \\
\hline C & フェ $\underset{\text { (水溶性剤) }}{ }$ & " 820 , & 2,960 \\
\hline D & 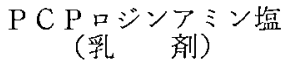 & $" 1$ & 1,000 \\
\hline $\mathrm{E}$ & (涿" 剂) & 劇 物 & 300 \\
\hline $\mathrm{F}$ & $\mathrm{P} \mathrm{C} \underset{\text { (水溶性用) }}{\mathrm{P}}$ & $"$ & 72 \\
\hline
\end{tabular}

第 6 表 市販防菌鄅の効果とカビの発生状況 カラマツ辺心材 $20^{\circ} \mathrm{C}, 85 \% \mathrm{R} . \mathrm{H}$

\begin{tabular}{|c|c|c|c|c|}
\hline \multirow{2}{*}{ 防 } & \multicolumn{2}{|c|}{ 経過月数 } & \multirow{2}{*}{ 胞子の色 } & \multirow{2}{*}{ 分離株数 } \\
\hline & 12 & 34 & & \\
\hline 有機ヨード系 & $\begin{array}{ll}0 & 0 \\
0 & 0 \\
0 & 0\end{array}$ & $\begin{array}{ll}0 & 3 \\
0 & 2 \\
0 & 0\end{array}$ & 黄 & 10 \\
\hline $\begin{array}{r}\text { 有機塩素系 } \\
(\mathrm{A})\end{array}$ & $\begin{array}{ll}0 & 1 \\
0 & 0 \\
0 & 0\end{array}$ & $\begin{array}{ll}1 & 1 \\
0 & 1 \\
0 & 1\end{array}$ & 緑，白 & 22 \\
\hline (B) & $\begin{array}{ll}0 & 1 \\
0 & 0 \\
0 & 0\end{array}$ & $\begin{array}{ll}2 & 2 \\
0 & 2 \\
0 & 1\end{array}$ & 緑, 黄 & 18 \\
\hline (C) & $\begin{array}{ll}0 & 0 \\
0 & 0 \\
0 & 0\end{array}$ & $\begin{array}{ll}1 & 1 \\
0 & 1 \\
0 & 1\end{array}$ & 黄 & 16 \\
\hline$"$ & $\begin{array}{ll}0 & 0 \\
0 & 0 \\
0 & 0\end{array}$ & $\begin{array}{ll}1 & 2 \\
0 & 1 \\
0 & 1\end{array}$ & 緑, 黄 & 19 \\
\hline 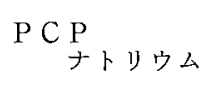 & $\begin{array}{ll}0 & 0 \\
0 & 0 \\
0 & 0\end{array}$ & $\begin{array}{ll}0 & 2 \\
0 & 1 \\
0 & 0\end{array}$ & 緑, 黄 & 11 \\
\hline 無 処 理 & 45 & & 緑, 黄 & 63 \\
\hline
\end{tabular}

染布 量 $100 \mathrm{~g} / \mathrm{m}^{2}$

処理液濃度 $\{$ P C Pナトリウム $0.1,0.5,1.0 \%$

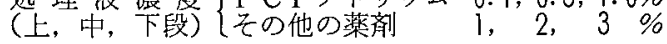

て良く生育する5までの間を0〜5の6段階に区 分して表示した。この結果いずれの薬剤もペンタ クロルフェノールの3〜10倍高い濃度である1〜 3\%液を使用すれば、2 月月間は充分有效である ことが判った。第7表は、このときの各薬剤処理 供試片に発生した青カビの種類と薬剈処理との関 連を示したものである。無処理材に認められなか 
第7表 各試料木片におけるカビの分布

\begin{tabular}{|c|c|c|c|c|c|c|c|c|c|}
\hline & & & 無 & & 処 & & & 理 & \\
\hline 分離落 & & & 理 & A & $\mathrm{B}$ & C & $\mathrm{D}$ & $E$ & $\mathrm{~F}$ \\
\hline Asperg & sillus & versi & 0 & 0 & $x$ & 0 & 0 & 0 & 0 \\
\hline$A$. & & repens & 0 & $x$ & $x$ & 0 & $\times$ & 0 & $x$ \\
\hline Penicil & lium & tans & 0 & 0 & $x$ & 0 & 0 & 0 & 10 \\
\hline$P$ & & spinv & 0 & 0 & $\times$ & $x$ & $x \mid$ & 0 & 10 \\
\hline$P$. & & $i m p r$ & 0 & 0 & $x$ & 0 & $\times$ & $x$ & 10 \\
\hline$P$. & & char & 0 & 0 & 0 & $x$ & $\times \mid$ & 0 & 10 \\
\hline$P$. & & pulvillorum & $0^{\circ}$ & $x$ & $x$ & $\times$ & $\times \mid$ & $x$ & $x$ \\
\hline$P$. & & corylophilum & $\times$ & 0 & 0 & $\times$ & $x \mid$ & $x$ & $x$ \\
\hline$P$. & & citr & 0 & $x$ & 0 & $x$ & $x \mid$ & $x$ & 10 \\
\hline$P$. & 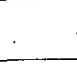 & tardum & $x$ & $x$ & 0 & $x$ & 0 & 0 & $x$ \\
\hline$\pi$ & 完 & 全 菌 & 0 & $x$ & $x$ & $x$ & $x \mid$ & $x$ & $x$ \\
\hline
\end{tabular}

った青カビで、処理材に発生した種類も2 種類あ ったが、処理した薬剤の種類によって若干発生し た青力ビの種類が異なった。とくに、B薬凨とC 薬剤では発生したカビの種類が相反し、B薬風で はAspergillus 属が全く発生しなかった。また、 一方のC薬剤では Penicillium 属の大部分の発生 を阻止できたが、Aspergillus 属は阻止できなか った。結局、両者を混合使用寸ればその相垂作用 と相俟って良好な阻止効果が期待された。第 8 表 は処理する材の含水率の影響（力ビの発生しやす さ、薬液吸収量の大小とのからみ) 女含めて確か める意味で予め高含水率材、低含水率材を調製乙 て薬液処理し、単一薬剤と混合薬剤の効力の差を 検討した結果を示したものである。その結果、䇥 処理の場合も低含水率材を高温高湿（今回の試験 では $\left.28^{\circ} \mathrm{C} 、 90 \%\right)$ の場所においた力が良くカビが 発生した。然しながら処理材では低含水率材が高 含水率材より薬凨吸収量が可成り大きかったため か両者に大きな差は生じなかった。また、混合薬 剤の方がそれぞれの単一薬剤より高い効力を示し た。今後、このよらな混合薬鼡が抗菌スペクトル
第 8 表 混合薬成の防カビ効果と薬液吸収量 カラマツ辺心材 2 週, $28^{\circ} \mathrm{C}, 90 \%$ R. H

\begin{tabular}{|c|c|c|c|c|c|c|c|c|}
\hline \multirow[b]{2}{*}{ 薬 㶡 } & \multicolumn{3}{|c|}{ 低含水率材 } & \multicolumn{3}{|c|}{ 高含水率材 } & \multicolumn{2}{|c|}{$\begin{array}{c}\text { 薬液吸収量 } \\
\left(\mathrm{g} / \mathrm{m}^{2}\right)\end{array}$} \\
\hline & 0.5 & 1.0 & 2.0 & 0.5 & 1.0 & 2.0 & 倠念水 & $\begin{array}{l}\text { 高含水 } \\
\text { 率材 } \\
\end{array}$ \\
\hline B 薬 剂 & $0 \sim 2$ & 0 & 0 & 1 & i & 0 & 171 & 92 \\
\hline C 薬 剂 & 2 & $1 \sim 2$ & 1 & $0 \sim 1$ & $0 \sim 1$ & 0 & 155 & 101 \\
\hline 莯, $\quad$ C 混合 & 0 & 0 & 0 & $|0 \sim 1|$ & $0 \sim 1$ & $0 \sim 1$ & 162 & 90 \\
\hline 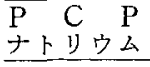 & 0 & 0 & 0 & 0 & 0 & 0 & 157 & 102 \\
\hline 無 処 理 & & 4 & & & 1 & & & 0 \\
\hline
\end{tabular}

の広い薬剤として開発される必要があると考えら れる。

\section{5. 拉わりに}

北海道の造林カラマッをはじめ、裏日本での北 洋カラマッ材を対象にしたカラマッ材の利用と加 工技術の開発は、今後益々発展することが予想さ れる。とくに、国内に扣计る将来の針葉樹生産を 考光るときは、カラマッ材の利用は避け得ない技 術問題であり、これと平行して防カビ処理技術も 現在以上に付加価値の高い形の製品処理技術とし て要求され、注目されるときが来ると思われる。 このときのために、より安全でより安定な低毒性 防カビ剤が供給されるよら、薬郕メーカー等関係 者の前進を期待してやまない。掞わりに、本試験 のための薬剤の提供を頂いた山陽木材防腐、山宗 化学、北海三共、神東塗料、武田薬品扣よび試供 品の提供を受けた各社研究室に感謝いたします。

\section{参考文 献}

1) 井上嘉幸: 本誌 2 号 31 (1975)

2）青島清雄：木材工業 30卷 11月号 28 (1975)

3）布村昭夫汪か：北林産陚月報，290号 5（1976）

4) Konstantinaja, A. A. : Bot. Z., Vol. 49, No. 1, 105 (1964)

5) Shields, J. K., et al : F. P. J., Vol. 23, No. 10, 28 (1973)

6) Hulme, M. A. : ibid., Vol. 25, No. 8,38 (1975)

7) Unligil, H. H. : ibid., Vol. 26, No. 1, 32 (1976)

8) F. P. L. : Wood Handbook, 17-2 (1974) 